\title{
Ethnic Identity and Other-group orientation on Javanese and Chinese Students
}

\author{
Zakki Nurul Amin ${ }^{1}$, Mungin Eddy Wibowo ${ }^{1}$, JT. Lobby Loekmono ${ }^{2}$, Sigit Hariyadi ${ }^{1}$, \\ Binti Isrofin ${ }^{1}$ \\ ${ }^{1}$ Guidance and Counseling Department Program, Faculty of Education, Universitas Negeri Semarang, \\ Sekaran, Gunungpati, Semarang City, Central Java, Indonesia \\ ${ }^{2}$ Guidance and Counseling Department Program, Teaching and Education Faculty, Universitas Kristen \\ Satya Wacana, Diponegoro Street 52-60, Salatiga 50711, Central Java, Indonesia
}

Email: zakki.nurul.amin@gmail.com

\begin{abstract}
Ethnic identity is an important component of the self-concept, which contributes to the formation of attitudes toward other groups. The current study focuses on Javanese and Chinese as two ethnic groups who are majority and minorities in Indonesia, purpose to investigate the direct and indirect effect between ethnic identity and othergroup orientation moderated by ethnicity. The multi-group ethnic identity measure (MEIM) was administered to 300 high school students (Javanese students $\mathrm{N}=157$; Chinese students, $\mathrm{N}=143$ ) and analyzed using Hayes PROCESS software. The results show that ethnic identity and ethnicity have direct effect on other-group orientation. Ethnicity also has significant effect as a moderator. These findings have implication to development guidance and counseling programs and improve other-group orientation on Javanese and Chinese students.
\end{abstract}

Keywords: ethnic identity; other-group orientation; Javanese student; Chinese student

\section{INTRODUCTION}

Ethnic identity as a psychological concept, separately and cannot be equated with personal identity as individuals, although mutually influence each other. Phinney [1] asserts that ethnic identity is a dynamic and multidimensional construct, referring to self-identity, or feeling as a member of a particular ethnic group. Ethnic identity focused on a feeling as a member of an ethnic group from the results of exploration and commitment.

Ethnic identity as part of the personal identity defined by Tajfel as cited in Phinney \& Ong [2] refers to sense of belonging to an ethnic group with internalized emotional values and interests on self as an individual. Ethnic identity can help a person to get information about personal identity and other groups, and also give someone a guide in choosing the attitude and orientation towards other groups.

Brook and Pahl [3] explain that cultural differences between ethnic groups affect personality, attitudes and behavior. The majority of research on ethnic identity focuses on the unique personality constructs that distinguish a particular ethnic group [4, 5]. But 
it is also important to study and distinguish between ethnic identity, correlation between groups, and its influence on the formation of attitudes, especially against other groups

Mejía [6] suggests that the behavior of someone with ethnic group can be seen from the study of ethnic identity. According to Erik Erikson's models of ego identity development, explaining that a person's personal identity becomes an important character that determines the attitude with others [7]. Phinney [1] also explain that the attitude toward other groups is important aspect of social interaction with the society.

This study focuses on the two ethnic groups in Indonesia, the Javanese and Chinese, their relationship is often described as a relationship of majority and minority [8, 9, and 10]. As the majority and minority groups, patterns of information processing and attitude formation often occurs because of the interaction process, in which one of the groups have a greater influence than any other group [11, 12].

The relationship and interaction between Javanese and Chinese occurred since tens of years ago on various segments of life. However, historical records writes that between Javanese and Chinese is limited by cultural factors, status, role, group, network interaction, and social institutions $[9,13]$. In fact, ethnic Chinese in Java as a minority group have an exclusive feeling and make their social sphere more with their group. The tendency of this attitude cannot be separated from past experiences and political circumstances that discriminate against minorities, including ethnic Chinese [9].

On the other hand, ethnic Javanese who still apply the cultural values have a collective attitude, respect for others, as well as having a positive orientation to the other groups. But the existing phenomenon, the value of Javanese culture is currently changing the modern value that is more individual [8]. The existence of cultural differences make each group, both Javanese and Chinese, show a pattern of different attitudes and behavior, including the orientation and attitude towards other groups [14].

\section{METHOD}

\section{Procedure and Participant}

The research design used in this study is correlational research design. Subjects in this study amounted to 300 high school students in Salatiga (Javanese students $\mathrm{N}=157$; Chinese students, $\mathrm{N}=143$; Male $\mathrm{N}=132$; Female $\mathrm{N}=168$ ) were taken by purposive sampling. Participants ranged in age from 14 to 20, with a mean age of 16.5. For those who agreed to participate in the research, will fill in a questionnaire that the researchers have prepared. The measures were administered during school hours.

\section{Instrument}

Multigroup Ethnic Identity Measure (MEIM) developed by Phinney [1] was examined for ethnic identity and other-group orientation. Overall it consists of 23 items and is a combination of two scale that is, ethnic identity scale, 14 item (e.g., I have spent time trying to find out more about my own ethnic group, such as its history, traditions, and customs), and other-group orientation scale, 6 item (e.g., I like meeting and getting to know people from ethnic groups other than my own), while the other 3 items are sub scale to show self-identification. But the other-group orientation scale analyzed only 5 items because there is one item that is not valid, i.e., "I enjoy being around people from ethnic groups other than my own". The 
statements that may agree or disagree are rated on a 4-point likert scale ranging from 1 'strongly disagree' to 4 'Strongly agree'. In the present study, ethnic identity instrument validity using product moment with score $(0.328-0.657)$, and instrument reliability using Cronbach's alpha was respectively: 0.791. While other-group orientation instrument validity score $(0.116-0.613)$, and reliability score $r=0.569$.

The current research used back translation procedure before the data retrieval process, i.e., "I have spent time trying to find out more about my own ethnic group, such as its history, traditions, and customs". After back translation analysis proses become "Saya meluangkan waktu untuk mencoba mengetahui lebih lanjut tentang kelompok etnis saya sendiri, seperti sejarah, tradisi, dan adat istiadat". In order to validate the Indonesian versions of the MEIM, the questionnaires were translated from English into Indonesian. The translated items, back-translation of the items into English and comparison of the back translation and original questionnaire to inform a final optimum version in Indonesian.

\section{Data Analysis}

Means and standard deviations were determined using IBM SPSS 22.0. Correlation and moderator analysis using bias corrected bootstrap method $\mathrm{N}=5000$ with 95\% confidential interval in PROCESS software installed on IBM SPSS 22.0. This current research based on model 1 templates for PROCESS for SPSS and SAS by Andrew Hayes [15]. PROCESS is an easy to use add-on for SPSS for statistical mediation, moderation, and conditional process analysis. It is widely used through the social, business, and health sciences for estimating direct and indirect effects in single and multiple mediator or moderator models. The conceptual model in this research is presented in Figure 1.

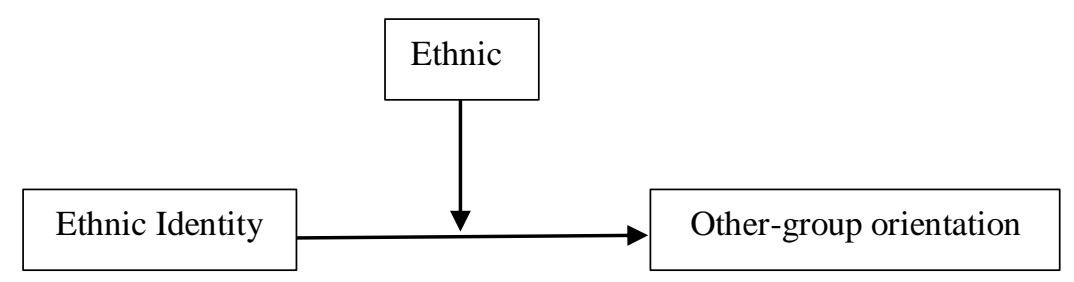

Figure 1 The Conceptual Model of EI and OGO Developed for Testing

\section{RESULT}

TABLE 1 DIRECT AND INDIRECT EFFECT ON OTHER-GROUP ORIENTATION

\begin{tabular}{ccccccccc}
\hline Predictor & $\boldsymbol{M}$ & $\boldsymbol{S D}$ & $\boldsymbol{B}$ & $\boldsymbol{S E}$ & $\boldsymbol{t}$ & $\boldsymbol{p}$ & $\boldsymbol{L L C I}$ & $\boldsymbol{U} \boldsymbol{L C I}$ \\
\hline EI & 28.62 & 6.59 & $0.23^{* *}$ & 0.76 & 3.06 & 0.00 & 0.08 & 0.38 \\
E & - & - & $7.04^{* *}$ & 2.03 & 3.46 & 0.00 & 3.04 & 11.04 \\
Mod: IE x E & - & - & $-0.15^{* *}$ & 0.04 & -3.08 & 0.00 & -0.25 & -0.05 \\
\hline
\end{tabular}

Note: $\mathrm{N}=300$. EI=Ethnic Identity; OGO=Other-group orientation; E=Ethnic, Ethnic was dummy coded such that $1=$ Javanese students and $2=$ Chinese students.

** $\mathrm{p}<0.01 ; * \mathrm{p}<0.05$. 
The means, standard deviations, direct, and indirect effect of all variables are listed in Table 1. The direct effect analysis using Hayes PROCESS show that ethnic identity (EI) have direct effect on other group orientation (OGO) $(\beta=0.23 ; p<0.01)$, and also ethnic have significant direct effect on OGO $(\beta=7.04 ; p<0.01)$. The current study also proved that ethnicity has the effect of interaction as moderator EI on OGO ( $\beta$ $=-0.15 ; \mathrm{p}<0.01)$. Conditional effect of EI on OGO at values of the moderator presented in Table 2 present.

TABLE 2 CONDITIONAL EFFECT OF EI ON OGO AT VALUES OF THE MODERATOR

\begin{tabular}{ccccccc}
\hline Ethnic & $\boldsymbol{\beta}$ & $\boldsymbol{S E}$ & $\boldsymbol{t}$ & $\boldsymbol{p}$ & $\boldsymbol{L L C I}$ & $\boldsymbol{U} \boldsymbol{L C I}$ \\
\hline $\mathbf{1}$ & $0.08^{*}$ & 0.03 & 2.40 & 0.02 & 0.01 & 0.15 \\
$\mathbf{2}$ & $-0.07^{*}$ & 0.04 & -1.98 & 0.04 & -0.15 & -0.00 \\
\hline
\end{tabular}

Note: $\mathrm{N}=300$. EI=Ethnic Identity; OGO=Other-group orientation; E=Ethnic, Ethnic was dummy coded such that $1=$ Javanese students and $2=$ Chinese students.

$* * \mathrm{p}<0.01 ; * \mathrm{p}<0.05$.

To facilitate the interpretation of interaction effect, Figure 2 presents the predicted ethnic identity value as a function of other-group orientation. Generate data for plotting on Hayes PROCESS shows that in Javanese students, the highest highest-level of othergroup orientation is owned by students with high level of ethnic identity (score 16.37). In addition that Chinese students, the highest highest-level of other-group orientation is owned by students with low ethnic identity (score 17.14).

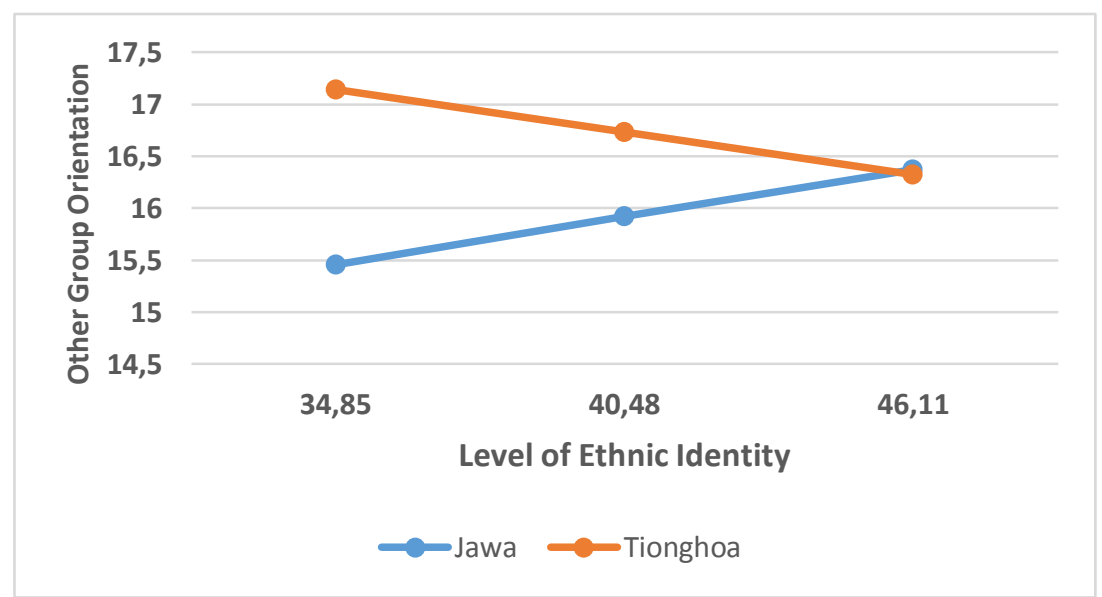

Figure 2 Predicted Ethnic Identity Value as a Function of Other-Group Orientation

\section{DISCUSSION}

This current research shows that ethnic identity and ethnicity have significant direct effect on other-group orientation. Through this research, it can be concluded that the relationship between EI and OGO is moderated by ethnicity. In other words, there are significant differences effect of EI on OGO in Javanese and Chinese 
students. The results of moderator effects on Javanese and Chinese students have different results. In Javanese students, the highest highest-level of OGO is owned by students with high level of EI, on the contrary, in Chinese students the highest highestlevel of OGO is owned by students with low EI

Kaiser [16] suggests that the culture of the environment and the community, as well as the interactions between the two ethnic groups contribute to the conviction of identity. For minority groups, one's orientation toward dominant society tends to have important implications [1,17-18]. Similarly for ethnic Chinese in Indonesia who have interacting and living together in the community.

Ethnic identity is meaningful only in situations in which two or more ethnic groups are in contact over a period of time. A commitment, or sense of belonging, is perhaps the most important component of ethnic identity [2]. It can be possible when viewing the Chinese students as a minority student who has lived and mingled with the majority group. They are not aware of their ethnic identity, no doubt become a minority having been mixed and try not distinguish themselves by racial things [19]

In contrast, to Javanese students as a majority group, positive attitudes toward other groups are supported by having a high ethnic identity. Duffy \& Klingaman [20] explained that stronger EI tend to be more open in the public's mind, giving rise to a positive attitude also to other groups. In addition, Javanese cultural values also teaches that with mutual respect and respect to create peace and tranquility.

The results of this study give attention to the cultural constructs of ethnic identity who are concerned with social constructs, other groups orientation. Ethnic identity (such as racial identity and acculturation) suggests that cultural factors influence a person's social development and it is possible there will be differences between members of different ethnic groups.

\section{CONCLUSION AND IMPLICATION}

This study provides an interesting results about ethnic identity, other-group orientation, and ethnicity. Results shows show that EI and ethnicity have direct effect on OGO. The current study also proved that ethnicity has the effect of interaction as moderator EI on OGO. Further analysis shows in Javanese students, the highest highest-level of OGO is owned by students with high level of EI. In contrast, the highest highest-level of other-group orientation among Chinese students is owned by students with low ethnic identity.

In general, the findings of this study have implications for counselors to understand the influence of the environmental context (ethnicity, ethnic identity) in the manufacture of attitudes toward other groups. Changing demographics, ethnic racial background, and the influence of family culture there is Indonesia contributed to the attitude of Javanese and Chinese students.

\section{REFERENCE}

[1] Phinney, J. S. 1992. "The multigroup ethnic identity measure: a new scale for use with diverse groups" Journal of Adolescent Research, 7, 156-176. 
[2] Phinney, J. S., \& D. Ong. 2007. “Conceptualization and measurement of ethnic identity: current status and future directions" Journal of Counseling Psychology, 54, 371-281.

[3] Brook, J.S and K. Pahl. 2005. "The protective role of ethnic and racial identity and aspects of an africentric orientation against drug use among african american young adults" J Genet Psychol, 166(3): 329-345.

[4] Iwamoto, D.K and W.M. Liu. 2010. "The impact of racial identity, ethnic identity, asian values and race-related stress on asian americans and asian international college students' psychological wellbeing" J Couns Psychol, 57(1): 79-91.

[5] Quiantana, S.M. 2007. "Racial and ethnic identity: developmental perspectives and research" Journal of Counseling Psychology, 54 (3), 259-270.

[6] Mejia, B.X. 2011. "Perceived career barriers: the role of ethnic identity, acculturation, and selfefficacy mediators among latina/o college students" Disertasi: Columbia University.

[7] Smith, T.B and L. Sylva. 2011. "Ethnic identity and personal well-being of people of color: a metaanalysis" All Faculty Publications, Paper 88.

[8] Martaniah, S.M. 1984. Motif sosial remaja suku jawa dan keturunan cina di beberapa SMA Yogyakarta. Gajah Mada University Press.

[9] Darmawan, Darwin. 2014. Identitas hibrid orang cina. Yogyakarta: Gading Publishing.

[10] Tan, M. G. 2008. Etnis tionghoa di indonesia (kumpulan tulisan). Jakarta: Yayasan Obor Indonesia.

[11] Martin, R., P. Y. Martin, J.R. Smith, \& M. Hewstone. 2007. "Majority versus minority influence and prediction of behavioral intentions and behavior" Journal of Experimental Social Psychology, 43, 763-771.

[12] De Dreu, C. K. W., \& N.K De Vries. 1996. "Differential processing and attitude change following majority and minority arguments" British Journal of Social Psychology, 35, 77-90.

[13] Suryadinata. 2003. "Etnis tionghoa, pribumi indonesia dan kemajemukan : peran negara, sejarah, dan budaya dalam hubungan antar etnis" Jurnal Antropologi Indonesia, 71.

[14] Amin, Z.N., M.E. Wibowo, dan E. Nusantoro. 2014. "Perbandingan orientasi karier siswa keturunan Jawa dengan siswa keturunan Tionghoa" Indonesian Jornal of Guidance and Counseling, 3(3), 8-16.

[15] Hayes, A.F. 2013. Model templates for PROCESS for SPSS and SAS. The Guilford Press, pp. 2.

[16] Kaiser, M. G. C. 2003. "The influence of ethnic identity, gender, and trait anxiety on career decision-making self-efficacy for white and racial/ethnic minority students" Disertasi: Seton Hall University

[17] Velden, F.S.T, B. Beersma, and C.K.W. De Dreu. 2007. "Majority and minority influence in group negotiation: the moderating effects of social motivation and decision rules" Journal of Applied Psychology, 92(1), 259-268.

[18] Kosic, M and C. Caudek. 2005. "Ethnic identification and outgroup attitude in minority and majority groups" Review of psychology, 12(2), 103-113.

[19] Phinney, J. S., G. Horenczyk, \& P. Vedder. 2001. "Ethnic identity, immigration, and well-being: an interactional perspective" Journal of Social Issues, 57(3), 493-510.

[20] Duffy, R. D., \& E. Klingaman. 2009. "Ethnic identity and career development among first-year college students" Journal of Career Assessment, 17(3), 286-297 